\title{
The Effectiveness of On-Street Parking Fees in Pangkalpinang City
}

\author{
Revy Safitri ${ }^{*}$, Ririn Amelia ${ }^{2}$, Jeanne Darc Noviayanti Manik ${ }^{3}$
}

\author{
${ }^{1}$ Department of Civil Engineering, Universitas Bangka Belitung, Bangka 33172, Indonesia \\ ${ }^{2}$ Department of Mathematics, Universitas Bangka Belitung, Bangka 33172, Indonesia \\ ${ }^{3}$ Department of Law, Universitas Bangka Belitung, Bangka 33172, Indonesia \\ ${ }^{*}$ Corresponding author. Email: revy.safitri@gmail.com
}

\begin{abstract}
Pangkalpinang City as Capital of Bangka Belitung Province become a center of various activities that attract high vehicle trips. The high vehicle trip requires more parking spaces. For providing more parking spaces in Pangkalpinang City, there are not only off-street parking provided but also on-street parking. The Government of Pangkalpinang City has established policies related to the determination of parking location and parking fees to manage on-street parking in this city. But, the implementation of parking fees policy in Pangkalpinang City has not run effectively. Therefore, it needs to know the effectiveness of the current onstreet parking fees. This study aims to determine the effectiveness of the current on-street parking fees in Pangkalpinang City. The result shows that the official on-street parking fees both for two-wheeled vehicles and four-wheeled vehicles are considered too low if compared to ideal fees. The official on-street parking fee for two-wheeled vehicles in Pangkalpinang City needs to be adjusted to the current fee or increased up to IDR 2505,00. Meanwhile, the on-street parking fee for four-wheeled vehicles in Pangkalpinang City also needs to be increased with the range IDR 2.377,00 until IDR 4.138,00. Furthermore, the result can be used as a consideration of the government for evaluating the on-street parking fees policy.
\end{abstract}

Keywords: parking fees, vehicles, government

\section{INTRODUCTION}

Vehicle trips may not move continuously, sometimes it needs to stop temporary or stop long that called parking [1]. Parking is the act of stopping the vehicle for a period of time and leaving it unoccupied [2]. Every vehicle trip requires parking at its destination, so parking is a vital component in the transportation system [3,4]. The parking vehicles need space for parking. If the number of vehicle trip increase so does the provision of parking spaces [5,6].

Pangkalpinang City as Capital of Bangka Belitung Province become a center of various activities that attract high vehicle trips. The high vehicle trip requires more parking spaces. For providing more parking spaces in Pangkalpinang City, there are not only off-street parking provided but also on-street parking. On-street parking is parking spaces that take place on the side of the public road, either legal or not [6]. Besides providing more spaces, onstreet parking also provides convenient access to destinations [7].

The Government of Pangkalpinang City has established policies related to the determination of parking location and parking fees to manage on-street parking in this city. Based on the regulation, the location of on-street parking in Pangkalpinang City is grouped in 4 Zones, consist of Zone A, Zone B, Zone C, and Zone D [8].

Zone A : Around Jl. Mesjid Jami'
Zone B : Around Ramayana and BTC Area

Zone C : Around Jl. Jenderal Sudirman

Zone D : Around Jl. Ahmad Yani

Parking fees or parking pricing means that users pay directly for using parking facilities. Besides that, parking fees can be used to manage parking demand [3][9]. Onstreet parking fees in Pangkalpinang City are determined at Rp 1.000,00 for two-wheeled vehicles, Rp2.000,00 for fourwheeled vehicles, and $\mathrm{Rp} 3.000,00$ for multi-wheeled vehicles [10]. Meanwhile, the implementation of parking fees policy in Pangkalpinang City has not run effectively. There is a difference between official and current on-street parking fees in the implementation of parking fees policy. Besides that, based on the result of on-street parking fees evaluation in The Central Business District in Pangkalpinang City, it was known that the official fees could still be increased followed by improving parking facilities [11]. On the other hand, trustworthy parking fees mechanisms is one of the essential basics that all cities need as the basis for effective parking policy [12]. Therefore, it needs to know the effectiveness of the current on-street parking fees. This study aims to determine the effectiveness of the current on-street parking fees in Pangkalpinang City. The result can be used as a consideration of the government for evaluating the on-street parking fees policy.

\section{METHODOLOGY}

This study took place in Pangkalpinang City. In this study, the effectiveness of the on-street parking fees is reviewed based on official and current parking fees with the ability and willingness to pay for parking users. Ability To Pay 
(ATP) is the user's ability to pay for the services received based on the income that is considered ideal, whereas Willingness To Pay (WTP) is the users' willingness to pay to issue rewards for the services obtained. Ability To Pay is analyzed based on income, transportation costs, parking fees, and the frequency of use of parking facilities. Meanwhile, Willingness To Pay (WTP) is the average parking fees that is willing to be paid based on the perception of parking users toward available parking facilities [13].

In this research, data was collected by distributing questionnaires to on-street parking users. Questionnaires were distributed to 100 respondents of two-wheeled vehicle users and 100 respondents of four-wheeled vehicle users that spread to 4 on-street parking zones in Pangkalpinang City. Noted that some data used in this paper was presented as well in the previous paper related to on-street parking fees in Pangkalpinang City [14].

\section{RESULTS AND DISCUSSION}

The results are shown in Figure 1 and Figure 2. Figure 1 shows the comparison graph of official and current fees with ATP and WTP values for two-wheeled vehicles. The graph presents that the value based on the user's willingness to pay is at IDR $1.556,00$ to IDR $2.000,00$. While the value based on the user's ability to pay is at IDR $1.556,00$ to IDR $3.816,00$. The ideal fee is determined based on average ATP and WTP value, so it finds that the ideal fee should be at IDR $1.615,00$ to IDR 2.505,00. Besides that, the graph shows that the current fees are twice from the official onstreet parking. On the other hand, the current fee is in the ideal fee range. If compared to the current fee and ideal fee, the official fee is the lowest value that means the official fee is considered too low. The official on-street parking fee for two-wheeled vehicles in Pangkalpinang City needs to be adjusted to the current fee or increased up to IDR 2505,00. Meanwhile, Figure 2 shows the comparison graph of official and current fees with ATP and WTP values for fourwheeled vehicles. The graph shows that the value based on the user's willingness to pay is at IDR $2.174,00$ to IDR $2.846,00$. While the value based on the user's ability to pay is at IDR 3.703,00 to IDR 4.810,00. Based on average ATP and WTP value, it finds that the ideal fee should be at IDR $2.377,00$ to IDR 4.138,00. The official fee is lower than the ideal fee. So, the on-street parking fee for four-wheeled vehicles in Pangkalpinang City also needs to be increased with the range IDR 2.377,00 until IDR 4.138,00.

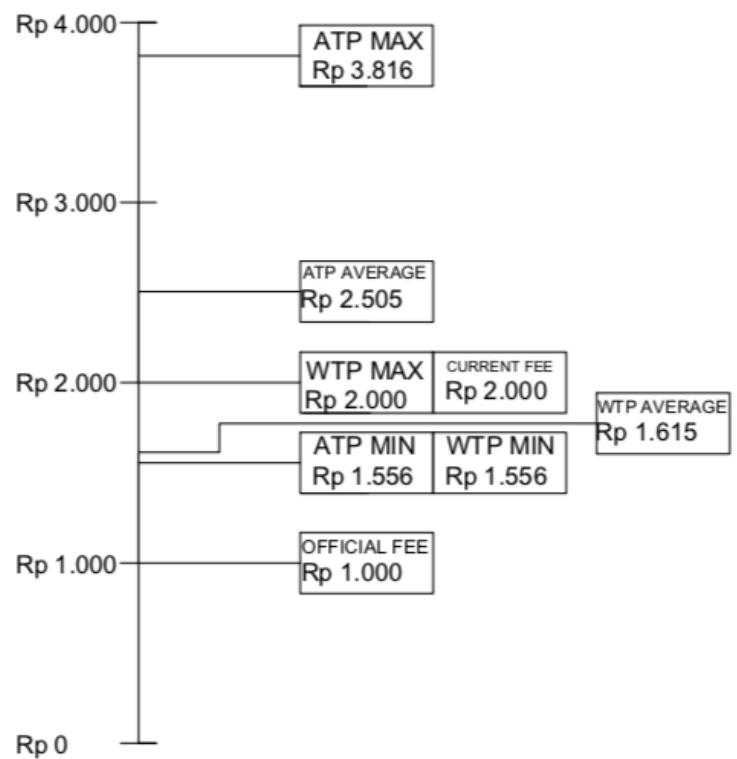

Figure 1 Comparison of official and current fee with ATP and WTP value for two-wheeled vehicles

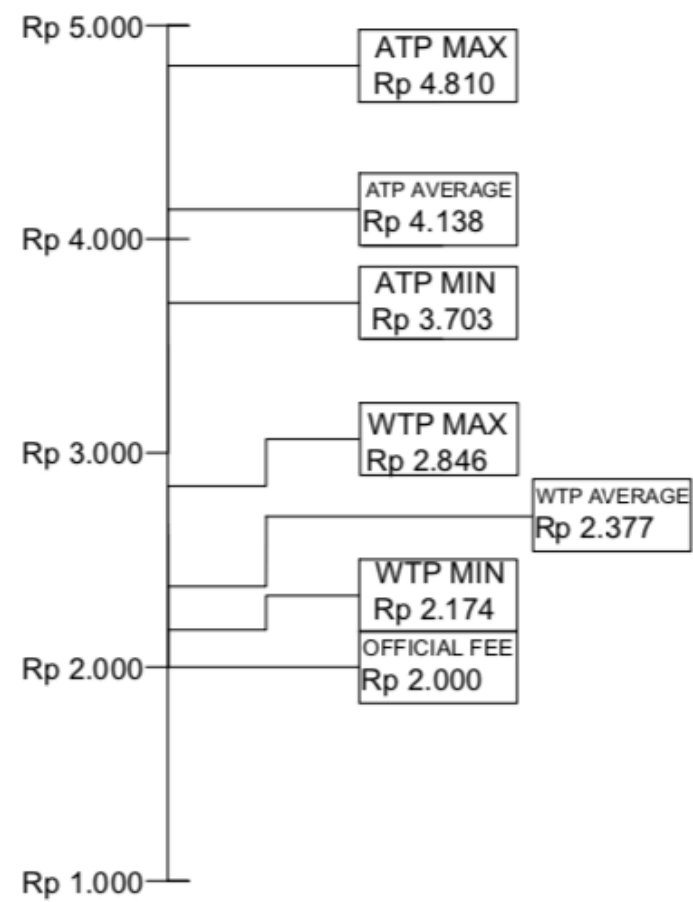

Figure 2 Comparison of official and current fee with ATP and WTP value for four-wheeled vehicles 
International Journal of Advance in Agricultural \& Environmental Engineering 3 300-4

The research findings show that the official on-street parking fees both for two-wheeled vehicles and fourwheeled vehicles are considered too low if compared to ideal fees. The official on-street parking fee for twowheeled vehicles in Pangkalpinang City needs to be adjusted to the current fee or increased up to IDR 2505,00. Meanwhile, the on-street parking fee for four-wheeled vehicles in Pangkalpinang City also needs to be increased with the range IDR 2.377,00 until IDR 4.138,00. Furthermore, the result can be used as a consideration of the government for evaluating the on-street parking fees policy.

\section{ACKNOWLEDGMENT}

This paper is part of the research that fully funded by Universitas Bangka Belitung through a funding scheme: Penelitian Dosen Tingkat Universitas Tahun 2019. Thank you to Universitas Bangka Belitung for supporting and funding the research.

\section{REFERENCES}

[1] Warpani S P 2002 Pengelolaan Lalu Lintas dan Angkutan Jalan (Bandung: Penerbit ITB)

[2] Presiden Republik Indonesia Undang - Undang Republik Indonesia Nomor 22 Tahun 2009

[3] Steiner R L, Meitin O and Plass M 2012 Impact of Parking Supply and Demand Management on Central Business District (CBD) Traffic Congestion, Transit Performance and Sustainable Land Use (Florida)

[4] Institute of Transportation Engineers 2016 Transportation Planning Handbook ed M D Meyer (Wiley)

[5] Yorgri E, Wen C and Hong L 2016 Parking Planning and Policy in the CBD of Accra, Ghana
[6] Rye T 2010 Parking Management: A Contribution Towards Liveable Cities Transport Policy

AdvisoryServices 1-50

[7] Mehta N, V P K and Juremalani J 2015 Review of Parking Problems in CBD Area of Urban Cities in Developing Countries International Journal for Innovative Research in Science \& Technology 1 377-9

[8] Walikota Pangkalpinang 2017 Keputusan Walikota Pangkalpinang No: 349/KEP/DISHUB/IX/2017

(Pangkalpinang, Indonesia)

[9] Litman T and Victoria Transport Policy Institute 2017 Parking Management Comprehensive Implementation Guide

[10] Walikota Pangkalpinang 2016 Peraturan Daerah Kota Pangkalpinang Nomor 5 (Tentang Perubahan Atas Peraturan Daerah Kota Pangkalpinang Nomor 16 Tahun 2011 Tentang Retribusi Jasa Umum)

[11] Safitri R and Amelia R 2018 Evaluasi Tarif OnStreet Parking berdasarkan Ability To Pay (ATP) dan Willingness To Pay (WTP) di Kawasan Plaza Pangkalpinang - Bangka Trade Center Kota Pangkalpinang (Batam: Konteks 12) pp 195-200

[12] Barter P 2013 Step by Step Towards Parking that Supports Sustainable Transport in Bogor

[13] Tamin O Z, Rahma H, Kusumawati A, Munandar A S and Setiadji B H 1999 Evaluasi Tarif Angkutan Umum dan Analisis Ability To Pay (ATP) Dan Willingnes To Pay (WTP) di DKI Jakarta 1 121-39

[14] Safitri R, Amelia R and Noviayanti Manik J D 2019 Evaluasi Tarif Parkir di Tepi Jalan Umum berdasarkan Zona di Kota Pangkapinang BENTANG : Jurnal Teoritis dan Terapan Bidang Rekayasa Sipil 7 104 